\title{
CONVERGENCES AND DIVERGENCES BETWEEN CHRISTIAN AND ISLAMIC REVELATION
}

\author{
Y.B. Prasetyantha
}

\begin{abstract}
:
Bagaimanakah caranya untuk lebih memahami ajaran kristiani tentang pewahyuan dalam perjumpaan dengan orang-orang yang beriman lain di Indonesia? Artikel ini ingin menjawab pertanyaan tersebut dengan mempraktekkan teologi komparatif. Artikel ini mencoba membandingkan secara fenomenologis doktrin kristiani tentang Allah yang dalam cinta kasih-Nya mewahyukan Diri dalam sejarah keselamatan yang memuncak dalam diri Yesus Kristus dengan ajaran Islam tentang Al-Qur'ān yang diyakini sebagai revelasi Allāh sekaligus kitab yang memuat petunjuk-Nya kepada manusia. Perbandingan yang difokuskan pada tiga aspek pewahyuan: subyek, obyek dan cara pewahyuan ini menampilkan adanya sejumlah persamaan sekaligus perbedaan antara kedua doktrin pewahyuan. Lebih dari itu, sebagai praktek teologi komparatif, penulis berhasil menunjukkan bahwa perbandingan dan refleksi teologis yang sederhana namun serius dan tulus ini dapat membuka cara-cara baru untuk semakin memperdalam iman Kristen akan Sabda Allah yang telah menjadi manusia dan, pada saat yang sama, untuk melampaui toleransi, yakni dengan penuh hormat menghargai iman saudarasaudari muslim.
\end{abstract}

Key Words:

God's mystery, revelation, salvation, Jesus Christ, Qur'ān

\section{INTRODUCTION}

This article is a part of a study in comparative theology. It is based on the assumption that we can deepen and enrich the Christian understanding of the living God and his plan for salvation revealed in Jesus Christ within the vast context of religious plurality by using the insights of Muslim tradition as a resource. In a spirit of dynamic ongoing understanding of Christian revelation increased by the living Church in different historical moments and in different cultural contexts and, at the same time, moving beyond openness to the religious dimension of the other believers, comparative theology attempts to faithfully provide an understanding of revelation and the content of faith in a way which meets the needs of our time and place so characterized by religious plurality.

The concept of revelation is the most fundamental one in many religions, especially in Christianity and Islam. Generally speaking, revelation is a divine communication to human beings. The phenomenology of religion uses five different criteria of revelation: origin or author, instrument or means, content or object, recipients or addressees, effect or consequence for the recipients. ${ }^{1}$ 
Phenomenologically, comparing and contrasting the above characteristics of revelation in both Christianity and Islam is immediately apparent that both convergence and divergence are present. To articulate our theological reflections, it would be worthwhile to view these phenomenological similarities and differences in detail, yet in this part we shall concentrate on only three aspects of revelation: (1) revealing subject, (2) revealed object, and (3) the manner of its revelation.

\section{THE SUBJECT OF REVELATION}

\section{Self-Revealing God}

The idea that it is God who is the author of revelation is a convergent one for these two monotheistic religions. Revelation is understood as coming from God, in Muslim interpretation, strictly from God-Allāh, alone. The Qur'ān speaks of wahy, which is the very act of revelation by Allāh to the prophets. "Truly it is the revelation of the Lord of all Being, brought down by the Faithful Spirit upon thy heart, that thou mayest be one of the warners, in a clear, Arabic tongue" (Qur'ān 26:192-195) ${ }^{2}$. It is a central part of Islamic belief that God, the sole Creator of the heavens and the earth who revealed his guidance and his mercy to the prophets since the beginning of the world, "finally" sent down (nuzūI) his kitāb to the last prophet, Muhammad.

Building on the Old Testament understanding of revelation, the New Testament and Christianity, since long before $\mathrm{Mu}-$ hammad's experience of revelation, sees and proclaims that God, the unknown, mysterious God, the Creator of the world, who has manifested himself in and through creation (Ac 17,23ff.; Rm 1,18ff.), revealed himself in and through the history of Israel and finally spoke to human beings in and through his Son, Jesus Christ (Heb 1, 1 ff.). In the Old Testament, the terms: glh ("to

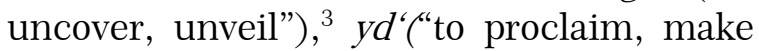
oneself known"), ${ }^{4}$ and nggd ("to report, communicate") 5 express clearly that the origin and author of revelation is no other than the hidden God. "All these contexts have this in common," as Johannes Deninger notes, "that God directs his word to human beings. For this reason, $d v r$ ("to speak") can frequently be used for the decisive communication on God's part. God's word to Israel is his most precious gift; in it he communicates himself: 'I am the Lord' (Gn. 28:13; Ex. 6:2, 6:29) and 'there is no other' (Is. 45:5, Jl 2:27)."

The New Testament, as does the Old Testament, understands that God is the subject of revelation. However, the New Testament writers stress more personal, active and mysterious aspects of God's selfmanifestation. Paul, for example, uses especially the words apokaluptein ("to uncover, unveil, remove from concealment"), phaneroun ("to make apparent or make manifest") and gnôrizein ("to make known") and phôtizein (to cast light on). ${ }^{7}$ Paul's basic theme is the uncovering of the mystery (mustèrion) that has previously been hidden and is now made manifest (Ep 1, 9; Col 1, 26). God, in Christ and through Christ, manifests to the world his mystery of salvation. God is the truly active one in the process of revelation. The personal, active and mysterious aspects of God's selfcommunication appear definitively in the person of Jesus Christ. God is invisible and unknowable. In and through Jesus Christ, the Son of God who alone knows him, God the Father -known as the beginning and end of the universe, who directed and inspired the salvific history of Israel beginning with Abraham, Moses and the prophets- is made visible and understandable (Jn 1,1418; 1 Jn 1,1 ff.).

Christianity differs completely from Judaism and Islam in its understanding that the person of Jesus Christ is "the image of the invisible God" (Col 1, 15; 2 Co 4, 4). Moreover, in the Christian view, Christ is not only God the revealer, but also God revealed. René Latourelle writes:

The true God whom He teaches is the God announced by Him and recognized in Him, so that in confessing the Son we confess also the Father. Christ is at once God who speaks and God who is spoken of, witness and object of testimony, author and object of revelation, He who reveals the mystery and the mystery itself in person. ${ }^{8}$ 
There is a difference between Islam and Christianity concerning the nature of God who reveals himself in their respective doctrines on revelation. Muslims see Jesus as a great prophet, worthy of great honor. It is through him and through other prophets but in its definitive form through Muhammad- the one and only God reveals his decrees, his mysterious will, the announcement of judgement and his divine law. Christians, however, believe that Jesus is the manifestation of the life and love of God. In and through Christ, for Christians, God the Father has revealed himself and gives himself to man. God the Father has fully revealed his plan of salvation by sending his beloved Son, Jesus Christ, and the Holy Spirit. "That in turn relates to a differing perception of the relation of God to the world -whether God remains the transcendent Will, ordering all things by sovereign power; or whether God shares in created being and raises it to participate in the Divine Life by the persuasive power of love." 9

\section{The Motive and Finality of God's Self- Manifestation}

Both Islam and Christianity affirm that God who reveals himself to human beings is the hidden, incomprehensible and transcendent God. The mystery of this Ultimate Reality whose nature is completely beyond and transcendent to this world remains an ineffable mystery even though it reveals itself to man, for Muslims by sending the Qur'ān down, for Christians through the incarnation of the God's Son.

On this point, it is interesting to examine how the respective communities try to understand the intention of God's selfmanifestation. Why does God, who transcends the world and, at the same time, is immanent in nature and in the human heart, communicate himself to human beings?

In the Muslim view, there is the one original will of God for salvation, which is intended for every nation. God makes the eternal covenant "between man and God by virtue of which man accepted the trust (amānah) of being an intelligent and free being with all the opportunities and dangers that such a responsibility implies." ${ }^{10}$ God proposes to man, even before the beginning of historical time and the creation of the earth, this covenant that is symbolized physically by the stone of the Ka'ba. ${ }^{11}$ In fact, the Qur'ān itself affirms that "God sent forth the Prophets, good tidings to bear and warning, and He sent down with them the Book with the truth" (Qur'ān 2:208). All God's messengers could sum up their proclamation in the words of the Qur'ān: "So set thy face to the religion, a man of pure faith - God's original upon which He originated mankind. There is no changing God's creation. That is the right religion; but most men know it not" (Qur'ān 30:29). Thus, "Muhammad did not really bring a new revelation. He repeated, corrected, and confirmed revelations which had been given to every people in some way." 12

By affirming the revelations or covenants given before the Qur'ān, Muslim doctrine sees the revelation sent down to the Prophet Muhammad as superior to all others. In a Muslim view, by sending the Qur'ān down, God would like to make verification of what came before it. The Qur'ān "is not a tale forged, but a confirmation of what is before it, and a distinguishing of everything, and a guidance, and a mercy to a people who believe" (Qur'ān 12:111). Muslims understand that unlike all previous scriptures, it is intended for all peoples. Moreover, based on the Qur'ān, they believe that the content of the Qur'ān is so protected that its text can undergo no alterations, deletions or additions. Therefore, for Muslims, the Qur'ān sent down to the Prophet is qualified in form and content to be the final and perfect revelation that will bring humankind to salvation.

The idea that God's revelation is an essentially salvific operation is, of course, not new to Christianity. This intention appears first of all in the very fact of revelation. God, by revelation, comes to meet a creature, a sinful creature. Such a move on the part of God can only mean friendship and salvation. Indeed, it is a central part of Christian revelation that God manifests and communicates himself in order to snatch man 
away from the death of sin and give him the gift of eternal life.

In contrast to the Muslim view, by realizing the fact that the whole of human history is marked by the original fault, Christianity understands God's self-manifestation as a new, free and gratuitous activity of God in history. Christians know Christ as the source of grace in order to know Adam as the source of sin. The Spirit-Paraclete, sent by the risen Christ, came to convict the world concerning sin by revealing him who is its Redeemer. ${ }^{13}$ Christians affirm that Jesus comes not only to fulfill the promises of the Old Testament, to teach a path of salvation, to make present God's mercy, but most of all He himself is the Savior of the world. He is the one who leads humans out of evil to unite with God, precisely because God is active in him in a unique way to accomplish such liberation.

By manifesting himself, God wishes to make man capable of responding to him, knowing him, and loving him far beyond his own natural capacity. On this salvific intention of revelation, René Latourelle writes:

The revelation of the Incarnation shows us in Jesus Christ, Incarnate Word, and the economy of love chosen by God to communicate this divine life. Revelation of our sonship shows us the nature of this communication: it is a certain extension of the life of the Divine Persons to human creation. God re-engenders His own Son in us and breathes His own Spirit into us. This elevation of mankind to the bosom and heart of God is essentially a mystery of salvation for the creature, for it makes creation share in the nature of God. ${ }^{14}$

In the last observation, we can say that the motive of God's self-manifestation should be founded in the nature of its source: God. Salvific revelation is a free act of divine sovereignty. It is a free initiative on the part of God and not the result of any previous request on the part of man. Man can neither expect nor demand it. In Islam, "revelation both emanates from God's mercy and leads back towards it." 15 In Christianity, revelation is self-giving of God who is love (1 Jn 4, 8.16). "For this is how God loved the world: he gave his only Son, so that everyone who believes in him may not perish but may have eternal life" (Jn 3, 16). God, out of the abundance of his love, speaks to us as a friend and draws us into the divine fellowship ( $D V 2)$. Christians believe that God's self-manifestation and selfcommunication has its origin in the unity of love within the Trinity. Revelation has its roots in the community of life of the Three Persons: Father, Son and Holy Spirit.

\section{THE OBJECT AND CONTENT OF REVELATION}

\section{The Deepest Truth about God}

It is obvious that, in Islam, the only God who creates the heavens and the earth is the subject of revelation and the Qur'ān is the objectivity of revelation. For Muslims, the Qur'ān is both the revelation of God sent down through the archangel Gabriel and the kitāb in which God's saving message to man is contained. This earthly Qur'ān is only the concrete revelation whose original archetype is with God in the Well-Guarded Tablet. The Qur'ān was sent in its entirety from the heavenly book above the seventh heaven down to the lowest heaven immediately above the earth. From this staging area Gabriel delivered bits and pieces of it to the Prophet Muhammad over a period of time in the human world. "Its sequences are relevant to human concerns, 'sent down' in relation to circumstance and need - as the whole idea of sha'n al-nuzūl or asbāb al-nuzūl (occasions of revelation) implies - and constituting, when interpreted, a source of guidance ( $h u d \bar{a})$ in various contexts." 16

The majority of Muslims hold the doctrines of the Qur'ān's eternity and its uncreatedness. "The Qur'ān is coexistent with God throughout all of eternity, a truth beyond and prior to the whole of created being. That truth lives and is communicated in the scripture of the Muslim community; indeed, it is the awareness of its inexpressible divine nature which makes the Qur'ān the scripture." 17 For Muslims the Qur'ān is the literal word of God from eternity to all humankind, "the eternal breaking through time; the knowable disclosed; the transcendent entering history and remaining here, available to mortals to handle and to 
appropriate; the divine become apparent." 18 But the Qur'ann is not God because "there is not god but He, the All-mighty, the All-wise. It is He who sent down upon thee the Book" (Qur'ān 3:4-5). In order to maintain God's unity, singularity and uniqueness, however, Muslims avoid going further to understand the nature of the Qur'ann, the uncreated word of God, as the source of God's self-knowledge. To give allegiance to other gods or to put trust in other beings except God is shîrk (lit. "Associating"), the greatest sin in Islam.

Based on revelation in the Old and New Testament, of course, the Christian faith confesses that God is one in nature, substance and essence. God is "the one, only Lord" whom Christian must love "with all your heart, with all your soul, with all your mind and with all your strength" (Dt 6,4-5; Mk 12,29-30). In the Christian view, it is the one God himself who is the subject and the object of revelation. "Before making known something, that is, his plan for salvation, God reveals someone, himself."19 God not only enters into history but, in order to manifest himself and to communicate his salvific plan, he also makes himself history. It is in and through Jesus of Nazareth -the Word made flesh- that God makes himself present to humanity. It is in and through Jesus Christ, the son of Mary and Joseph, that humanity was able to hear, see, watch and touch the living and loving God. In Christ, humankind has an event in which God makes himself known. Since God reveals nothing less than himself, there is a perfect identity between God the revealer and God the revealed, as the New Testament testifies.

The synoptic tradition describes primarily the economy of the historical manifestation of Christ. "He went around the whole of Galilee teaching in their synagogues, proclaiming the good news of the kingdom and curing all kinds of disease and illness among the people" (Mt 4, 23). In and through Jesus Christ, the kingdom of God, whom he calls his "Abba," is present and at work. This mystery of the overall God's selfmanifestation to humanity, for St. Paul, is no other than Jesus Christ with his unfathomable riches, his treasures of wisdom and knowledge. Concretely, the mystery of the word of God is Jesus Christ, the Son, who alone knows the Father and his secrets, and communicates this knowledge to whomever he will. For this reason St. John confesses Jesus Christ as the eternal word of God, not only the word who was "uncreated" or "coeternal with God" but also "the Word who was God" (Jn 1, 1).

Following the apostolic tradition, therefore, the Church confessed at the first ecumenical council at Nicea (325) that the son is "homoousios ("consubstantial") with God the Father, that is, one single God with him. $^{20}$ The second ecumenical council, held at Constantinople in 381, kept this expression in its formulation of the Nicene Creed and confessed that Jesus Christ is "the only-begotten Son of God, generated from the Father before all ages, Light from Light, true God from true God, begotten, not made, one in being with the Father, through whom all things were made." ${ }^{11}$

It is obvious that in Christianity the core of God's self-manifestation consists of the mystery of Jesus Christ. Christ's whole earthly life -his words and deeds, his silences and sufferings, indeed his manner of being and speaking- contains the fullness of God's revelation to the world. It is in and through the mysteries of Christ's person from the incarnation to the paschal mystery, including death on the cross, the resurrection and the ascension- humankind can meet and enter into the mystery that is hidden in God, that is, the mystery of God's being itself. In short, the encounter with the mystery of God's self-manifestation in and through Christ leads man to an encounter with the heart of the mystery of the deepest truth about God. In Rahner's words, the three divine Persons as they are revealed and act in the history of salvation is the immanent Trinity because:

[...] In God's self-communication to his creation through grace and Incarnation God really gives himself, and really appears as he is in himself, then with regard to that aspect of the Trinity in the economy of salvation which is given in the history of God's self-revelation in the Old and New Testaments we can say: in both collective and individual history of salva- 
tion there appears in immediacy to us not some numinous powers or other which represent God, but there appears and is truly present the one God himself. In his absolute uniqueness, which ultimately nothing can take the place of or represent, he comes where we ourselves are, and where we receive him, this very God himself and as himself in the strict sense. $^{22}$

\section{The Mystery of Man's Salvation}

The finality of revelation is for the salvation of man. God, in a Christian view, does not reveal himself in order to satisfy the curiosity of man, but rather to save him. Rahner says, "The Trinity is a mystery of salvation, otherwise it would never have been revealed." ${ }^{23}$ In Islam, even though the term "salvation" in the common theological sense is not known, it can be said that, as Toshihiko Izutsu notes, "The Koranic thought as whole is concerned with the problem of salvation of human beings. If it were not for this problem, the Book would not have been 'sent down', as the Koran itself explicitly and repeatedly emphasizes." 24

In the Qur'ān, in fact, the term salām, verbal noun from salima "to be safe, uninjured", is used as substantive in the meaning of "safety, salvation", thence "peace" (in the sense of "quietness"), thence "salutation, greeting." The word is of frequent occurrence in the Qur'ān. The oldest passage that contains it is the sura 97 where it is said of the Laylat al-Kadr ("the Night of Power") when the Qur'ān is sent down, "Peace it is, till the rising of dawn" (Qur'ān 97:5). Salām means salvation in this world as well as in the next. ${ }^{25}$

In Islam, as we have described in the beginning of this article, there is a much more positive attitude towards human nature. The original fall is the result of Satan's first deception of humankind. It does not have the consequence of separation from God. "Humankind, the qur'annic word is insān, is forgetful, impulsive and in a sorry state, fi khusrin (Q 103:2). One has to endure hardships from which one would otherwise have remained exempt. One needs guidance, however, not redemption." ${ }^{26}$ Like the guidance given through the prophets before Muhammad, The Qur'ān is sent down in order to guide man to obtain salvation.

The essence of the Qur'ān is a warning to submit (aslama, whence the noun "submission," islām) to the will of God. As 'abd, slave or servant of God, according to the Qur'ān, man is called to be muslim, one who submits to God. Muslims believe that the revelation to the Prophet Muhammad provides the matrix for this Islamic life and so gives assurance that from within this life the faithful will gain salvation. The Qur'ān with two inseparable dimensions, oral as well as written, is primarily a guidance of religious and moral principles and exhortations. "In terms of content, the bulk of the Qur'anic message contains exhortations dealing with righteous conduct, and the consequences of following or ignoring them." ${ }^{27}$ If a human being accepts this guidance, he or she shall not go astray nor be unhappy and on the day of resurrection he or she will enter heaven.

However, it is also true that "Islam is a system of belief, ritual and law, and its legal system covers all spheres of life." ${ }^{28}$ Islam, as the Qur'ān teaches, is a religion to be practiced, and five obligations called the five Pillars are required of every Muslim. By fulfilling these obligations and remembering God often, the Muslim is assured of God's favor on the earth and at the judgement. On this point, in Islam, it seems that salvation, or better salām, is like an "autoredemption." ${ }^{29}$

But those who believe, and do righteous deeds, those are the best of creatures; their recompense is with their Lord Gardens of Eden, underneath which rivers flow, therein dwelling forever and ever. God is well-pleased with them, and they are well-pleased with Him; that is for him who fears his Lord” (Qur'ān 98:7-8).

In Islam, salvation is obtained by struggling on the path of God (jihād), that is, "to transform both one's self and society, [...] that is simultaneously a struggle and praxis." 30 Muslims believe that this ceaseless struggle in the earthly journey towards God merits salvation because each soul will be 
rewarded for what it has done as is recorded in the heavenly kitäb. This autoredemption, however, should be understood in the Islamic context of a binding relationship between practice or righteous deeds and faith, between islām and ìmān — both trust in God's mercy and fear of the reality of the day of judgement.

Contrasted with Islamic theology, it is obvious that the word "salvation" is one of the most important words in Christian doctrine on revelation. God's self-manifestation in and through Jesus Christ, for Christians, is not only guidance to humankind to obtain salvation. It is salvation. In short, revelation is salvation.

Christian doctrine concerns itself first with revelation in the history of salvation, that is, the objective events in the history of salvation in which God intervened at opportune moments, chosen by him. From Abraham to Jesus Christ, as the Old and New Testaments testify, there are events where God manifests himself as an all-powerful and saving God. Within this series of the promise and fulfillment, however, there is only one plan of salvation that God intends for humankind, in fact, for all things. Christians consider the Christ-event as both fulfillment and fullness. "At many moments in the past and by many means, God spoke to our ancestors through the prophets; but in our time, the final days, he has spoken to us in the person of his Son whom he appointed heir of all things and through whom he made the ages" (Heb 1,1-2).

Jesus is not communicating an objective set of doctrines but a presence of God. He mediates God and God's salvation both by his words and his deeds. Jesus is a preacher. In the same manner as the prophets and John the Baptist, Jesus preaches the good news of the Kingdom and the penance that leads to the Kingdom. What he holds out to people is not a static possession of God, but a way to the Father. Jesus is a teacher. Being different from the other teachers in Israel, his teaching has an absolutely unique character. He stands out by the wisdom of his teaching as well as by the authority of his person. He speaks with the authority of God, his Father. He is anointed with the
Holy Spirit. In addition, Jesus heals, reconciles, casts out devils and raises the dead. He is invested with a unique and irrepressible power, which annihilates his adversary and renews everything, body and soul. Wherever Christ is, the power of salvation and life of the living God is at work.

Furthermore, "the coming of Christ inaugurates a new world, the world of grace; it effects a revolution, the revolution of salvation through the cross." ${ }^{1}$ Jesus does not deny death, which is the concrete manifestation of humanity's sin and its alienation from God, but accepts the most extreme face of the unsafe human condition damaged by sin as the supreme expression of submission to God. It is because of Christ's obedience, his trust and his love as the Son, that "God raised him high, and gave him the name which is above all other names" (Ph 2, 9). "God raised him from the dead and gave him glory" (1P 1, 21). The passage from Christ's death to his resurrection reveals that man is not saved by his own efforts but by God's unconditional compassionate love.

The cross of Christ represents the extreme form of unreason and the most bewildering and illusory victory possible of the forces of evil over him who is life and power. But at the same time the cross is the revelation of a love that wins the day over evil, not by force or by love that overwhelms, but by an excess of love that consists in accepting death from the very hand of the beloved and enduring the punishment meant for the beloved, in the hope that rebellious love will become love again. The all-weakness of God then becomes the all-powerfulness of God. [...] Henceforth we are the children of God, and his Spirit dwells in us. But in order to alter our condition in this manner, God had to become one of us; without himself knowing sin, he had to cross the gulf of absence that had been opened up by human rejection and rebellion. Only the action of the Son of God with his two natures, divine and human, could assume such a mission. Christ is the only point of convergence in which all things are fulfilled, surpassed, abolished, and replaced by the one work that God accomplishes as a human being and that God alone, as a human being, can accomplish. The seri- 
ousness of the crucified Christ who has been delivered up for us must be matched by the seriousness of our love, which allows all rebellion, all rejection, to be melted down in the white heat of the Trinity's love. ${ }^{32}$

Christians believe that the Christ-event, especially his death and resurrection, not only reveals the deepest mystery of the Trinity but also inaugurates the fullness of man's salvation. In and through Jesus Christ, man has been reconciled with God. "One man's offence brought condemnation on all humanity; and one man's good act has brought justification and life to all humanity. Just as by one man's disobedience many were made sinners, so by one man's obedience are many to be made upright" (Rm 5, 18-19). In and through Jesus Christ, in addition, human beings have received "the power to become children of God" (Jn $1,12)$. "All who are guided by the Spirit of God are sons of God; for what you received was not the spirit of slavery to bring you back into fear; you receive the spirit of adoption, enabling us to cry out, Abba, Father" (Rm 8,14-15). God's self-manifestation and self-giving in and through Jesus Christ is both man's redemption-restoration and man's deification-reunification. "The Son of God became the son of man," using Athanasius' words in his On the Incarnation, "so that humans, the children of Adam, might become children of God ... shares in the life of God. ... He is Son of God by nature, we by grace." ${ }^{33}$

Christians believe that it is through the power of the Holy Spirit received in the sacraments of Baptism and Confirmation that they are in contact with the risen Christ and, therefore, become both the children of God in the Son and the new creation in the Last Adam. Being Christian is a present reality of salvation. It is also both the early produce of and the promise of future salvation. "We were enslaved to the elemental principles of this world" (Ga 4, 3), but "Christ set us free" (Ga 5, 1). In this justified state, "the priority is indeed praxis, not argument, nor even the conviction that God is good. The priority is being a redeemed, liberated and liberating person." 34 The possession of "the first-fruits of the Spirit" (Rm 8, 23) means that by "realizing that as long as we are at home in the body we are exiled from the Lord" (2 Co 5, 6) we become capable of discharging the new law of love (Rm 8, 1-11). Salvation means at once to receive "the pledge of our inheritance" (Eph 1,14) and "the duty to battle against evil through manifold tribulations and even to suffer death" ( $G S 22)$. In the words of E. Schweizer:

The new creation of man by the Spirit is not a flight of faith into heaven or an abandonment of this imperfect world. On the contrary, the new creation means beginning to see the world as it is, suffering with it and taking its suffering to heart. The work of the Spirit is to make us aware of our solidarity with the world..$^{35}$

"All the faithful of Christ, of whatever rank or status, are called to the fullness of the Christian life and to the perfection of charity" ( $L G 40$ ), while awaiting in hope the grace of final perseverance and the recompense of God their Father for the good works accomplished with his grace in communion with Jesus. ${ }^{36}$ Christians don't hope in justification, from the moment that they have received it, but in its full and definitive realization when Christ returns in glory (cf. Rm 8, 23; 2 Co 1, 22; 5, 5; Ep 1, 10.14). By responding freely to God's selfcommunication through his Son and in the Spirit, the Church, the community of the new creation, advances towards its final fulfillment, that is, sharing in the mystery of blessed communion with the Most Holy Trinity.

\section{THE MANNER OF REVELATION}

"It is only in Christian and Islamic belief that something of ultimate significance has already taken place in history, so that the passage of history is divided by an insurmountable caesura into the age of the provisional and the age of the eternal." ${ }^{37}$ The fundamental difference between the two religions lies in the question of how Christianity and Islam respectively see this final divine communication to human beings. For Christianity, finality of revelation is given through the Incarnation of the Word of God among Jews 2000 years ago; for Islam, through the recitation of the 
Word of God to Arabic Muhammad 1400 years ago.

In Islam there is theological divergence on the modes of revelation among Muslim authorities. The Qur'ān itself outlines three modes of revelation: by inspiration (wahy), from behind a veil and by sending of a messenger ${ }^{38}$ In the case of the Qur'ān, Muslims hold that it is a malak ("angel or heavenly messenger") that "have uttered the direct words of God into Muhammad's ear and/or heart while he was in a state of ecstasy so that he would later recall the exact words." 39 In other words, it is the angel who is named Gabriel and identified with the Holy Spirit (rūh al-qudus) ${ }^{40}$ - is the agent of revelation sent to Muhammad. Carefully maintaining the distance between God and mankind, the Islamic tradition holds that the almighty and wise God sent his authority and knowledge symbolically contained in the Qur'ān down orally to the Prophet through the medium of the Angel Gabriel. ${ }^{41}$

According to Islamic tradition, this "descent" of the Qur'ān took place in three stages. ${ }^{42}$ First, from God to the Heavenly Book to which the qur'anic terms "Essence of the book" (umm al-kitāb, Qur'ān 43:4), "hidden book" (kitāb maknūn, Qur'ān 56:78) and "guarded tablet" (lawh mahfüz, Qur'ān 85:22) collectively refer. Second, the Qur'ān was sent in its completeness from the Guarded Book above the seventh heaven down to the "Abode of Honour" (bayt al-'izzāh) in the lowest heaven on the Night of Majesty (laylat al-qadr). ${ }^{43}$ Third and final, from the Abode of Honour, Gabriel delivered bits and pieces of it as needed during the period of Muhammad's prophethood. On this point, it should be noted that Muslims do not really speak of the "history of the Qur'ān." The Qur'ān, for Muslims, is the uncreated Word of God whose nature is unfathomable and unknowable by human reason. Thus, it is easier to speak of the history of its revelation that the Prophet experienced and of the history of the written text.

For Muslims, "the Qur'ān as the compilation of the "Speech of God" does not refer to a book inspired or influenced by God or written under the guidance of His Spirit: rather it is viewed as God's direct speech." ${ }^{44}$ Muslims believe that God spoke with his own voice in responding to the requirements of society over a period of twentythree years through Gabriel who precisely and faithfully recited it in stages to the Prophet Muhammad who passively received and repeated it verbatim to his followers for recording. The Qur'ān was the speech of God without intervention or participation from Gabriel or Muhammad in the construction or arrangement. Because the Qur'ān is wholly divine, the process of Qur'anic revelation is always an exclusively divine activity.

Shabbir Akhtar in his article An Islamic Model of Revelation makes a central distinction between the genesis of scripture and its interpretation. Because it, with regard to the genesis of its claims, begins as well as ends within the territory of the divine intelligence, according to him, the Qur'ān, then, is from God and is not in any way co-authored. "The scripture simply passes through 'the Muhammad mind' much as a grain of corn will pass undigested through the body of a bird." ${ }^{45}$ Muslims strictly hold that "during the period of trance, then, the prophetic intelligence and volition are completely suspended, there is no conscious participation in authorship, no active recipience of the revealed literary materials. This doctrine is about the genesis of scripture, not its interpretation." 46

To a Muslim interpreter, still according to Shabbir Akhtar, the question of the nature of the prophetic experience is of no interest at all. He says, "What matter is that however tanzīl works, Muhammad has no active role in it that could compromise or attenuate the divine initiative, let alone seek to induce such initiative whether authentically or as a personal illusion." 47 "Muslims maintain that Muhammad always made a clear distinction between his own speech and that which he claimed to receive from God." 48 During his experience of qur'anic revelation, Muhammad was absolutely passive. But, "once the Prophet is in a normal state, he is simply an Arab reader, an active interpreter who discerns the full significance of the inspired utterances." ${ }^{49}$ 
As God's chosen messenger, for Muslims, Muhammad is at once the recipient and the first and most authoritative interpreter of God's revelation. In fact, the Prophet has become the first Muslim among his community; and his response to the Qur'ān's message becomes the model (uswa) for the believers. His Hadth and Sunnah, his sayings and actions, are after the Qur'ān, the most important sources of the Islamic tradition.

We can equate Muhammad's role in Islamic revelation with the Virgin Mary's role in the economy of the Word as the Sacred Scriptures and Christian Tradition show and draw attention to it. Since he wished in his free and gracious love to effect the salvation of the world, "when the completion of the time came, God sent his Son, born of a woman... that we could receive adoption as sons" (Ga 4,4-5). He came down from heaven and was incarnated by the Holy Spirit from the Virgin Mary for us men, and for our salvation. Of course, for Christians, "there is only one God, and there is only one mediator between God and humanity, himself a human being, Christ Jesus, who offered himself as a ransom for all" (1 Tm 2,5-6). But Christians, especially Catholics, hail Mary as a "preeminent and singular member of the Church, and as its type and excellent exemplar in faith and charity" (LG53).

In Christian revelation, as we have already examined above, everything is God coming first, everything is grace: the activity of God coming out of his mystery, the economy of the word, the message of salvation, the capacity of responding to this message and meeting God in faith. This activity of God, however, does not encroach upon human freedom. Man remains free to accept or deny this other freedom that is open to him. Revelation is an encounter, essentially interpersonal that presents always both the seriousness of choice and the invitation of the depth of communion. In this context, human response to God's loving word is "not submission to the arbitrary will of God, who is pleased to claim the homage of the human mind, but rather man's recognition of God's plan of love and his free entry into that plan, it is an overture to divine friendship, inviting us to a share in God's own life."50

Christians see that in Mary's life there was really and fully an encounter between God and man. Vatican II presents the dynamic dialogue in love in the whole life of Mary as follows:

Adorned from the first instant of her conception with the radiance of an entirely unique holiness, the Virgin Mary of Nazareth is greeted, on God's command, by an angel messenger as "full of grace" (cf. Lk $1: 28$ ), and to the heavenly messenger she replies: "Behold the handmaid of the Lord, be it done unto me according to thy word" (Lk 1:38). Thus Mary, a daughter of Adam, consenting to the divine Word, became the mother of Jesus, the one and the only Mediator. Embracing God's salvific will with a full heart and impeded by no sin, she devoted herself totally as a handmaid of the Lord to the person and work of her Son, under him and with him, by the grace of almighty God, serving the mystery of redemption. Rightly, therefore, the holy Fathers see her as used by God not merely in a passive way, but as freely cooperating in the work of human salvation through faith and obedience. ... Comparing Mary with Eve, they call Mary "the Mother of the living," and still more often they say: "death through Eve, life through Mary." ( $L G 56)$

Being understood in the light of the great design of revelation in the history of salvation, for Christians, Mary's partnership has an utterly unique and central role for the genesis of the Word of God in the history. It is by her "fiat" to God's salvific will that the eternal Word of God became flesh and dwelled among us. It is by the participation of her, who is predestinated to be the mother of his Son, that God makes the Divine reality itself present in a particular historical form and in a particular historical individual. It is precisely in this respect in which Christian revelation differs much from the Islamic understanding of God's revelation, as Keith Ward notes:

The life of Jesus, for a fully incarnational form of Christian faith, is the selfexpression of the Eternal in time. Here the form of Supreme Goodness is fully realized in the particular; revelation is 
primary a making-present of Supreme Being and Goodness in a person. This is not, as in Islam, the revelation of a set of propositions, as though God were dictating laws or doctrines to be carefully written down. ${ }^{51}$

From this fact, it also becomes clear that, for Christians, the maternal participation of Mary in no way obscures or diminishes the unique mediation of Christ, but rather shows his power. In and through the life of Mary, the Word of God, who before the ages was born of God the Father, has assumed a human nature as his own. It is in the mystery of the one person (prosopon) of Jesus Christ, the God-man, the same perfect in divinity and perfect in humanity without confusion (asygchytôs) and without division (adiairetôs), ${ }^{52}$ Christians believe that the God who communicates himself and the man who accepts God's selfcommunication become irrevocably one.

The Sacred Scriptures testify that the mystery of God's self-communication to the world comes in the form of promisefulfillment in Israel's history of salvation. In the Old Testament, God's action toward Israel in the course of its history is always understood as revelatory in the strict sense; it is already the word of God. But the precise content of this word becomes intelligible only through the word of the prophet who explains the presence and content of God's activity. In other words, God reveals himself through historical events; historical events as divinely interpreted by the prophets who are directed and illuminated by God's spirit. Revelation is incorporated in events of history. There is the complementary character of historical events and events of the word that makes revelation grow.

"The structure of revelation, in the New Testament, is not essentially different from that of the Old." ${ }^{53}$ What is unique and definitive in the New Testament is that the event and the word are found in the same person. God himself, in person, revealed himself concretely in Jesus Christ. "Christ is at once the event and the interpretation of the event." ${ }^{54}$ The Incarnation is the way chosen by God to reveal himself and his plan of salvation. It means that all the re- sources of human nature are used by God to serve as the expression of the knowledge and love of the only true God. In fact, the whole of Christ's human existence, his words and actions, are completely utilized to reveal the depths of the divine mystery and, at the same time, to bring into reality the mystery of man's salvation. Of course, the Incarnation of the Word of God is one part of the total picture of God's action in history of revelation. Based on the New Testament's faith, however, Christians consider the Christ-event as the unsurpassable climax of all revelation. Karl Rahner explains this point clearly:

[...] The history of revelation has its absolute climax when God's selfcommunication reaches its unsurpassable high point through the hypostatic union and in the incarnation of God in the created, spiritual reality of Jesus for his own sake, and hence for the sake of all of us. But this takes place in the incarnation of the Logos because here what is expressed and communicated, namely, God himself, and, secondly, the mode of expression, that is, the human reality of Christ in his life and in his final state, and, thirdly, the recipient Jesus in grace and in the vision of God, all three have become absolutely one. In Jesus, God's communication to man in grace and at the same time its categorical self-interpretation in the corporeal, tangible and social dimension have reached their climax, have become revelation in an absolute sense. But this means that the event of Christ becomes for us the only really tangible caesura in the universal history of salvation and revelation, and it enables us to distinguish a particular and official history of revelation within the universal history of revelation before Christ. ${ }^{55}$

Christians hold that the God who is proclaimed as wholly transcendent in the Old Testament is experienced as the immanent and personal God in Christ. The immanence here in question is a superior one, qualitatively different from the indwelling of God's Spirit in the prophets. Jesus of Nazareth is not only the divine emissary inspired by the Spirit who comes to speak on God's behalf, rather he is the Christ consecrated with the Holy Spirit. Christ's entire life, from his birth to his 
death and resurrection, unfolds in the presence of the Spirit. By the power of the Holy Spirit who cooperates uninterruptedly, Jesus Christ does the Father's will with total obedience. We can say that if the prophets have the divine pathos by inspiration, Jesus Christ has it by nature. Indeed, he is the pathos of God. "No one has ever seen God; it is the only Son, who is close to the Father's heart, who has made him known" (Jn $1,18)$. And, at the same time, "the one who went down is none other than the one who went up above all the heavens to fill all things" (Ep 4,10). It is properly in the Incarnation of the Word of God from the annunciation to Easter that at once God's selfgiving to humanity and man's response in obedience to it reaches it goal. We can say that Christians consider the event of God's Word became man as the "fullness of time." There will be no other full and complete word than this time when, as René Latourelle states:

He [God] unites hypostatically with human nature and makes known His plan of life through the words, actions, gestures, attitudes, and the whole conduct of Christ. In Jesus Christ, the eternal and interior Word of God echoes without and makes Himself heard by man through the ways of flesh. Ever after, all knowledge of the true God, just like all true salvation, comes to us through Christ. ${ }^{56}$

\section{CONCLUSION}

By analysing without judgment or effort to prove something, we have challenged ourselves to clarify our understanding of Christian revelation by the light of both the similarities and differences between the two doctrines on revelation. The reflections, focusing especially on three aspects of revelation, have brought us some features which are specific to Christian revelation: incarnational principle, principle of historicity, principle of "economy", and inseparable relation between revelation and Trinity.

On one hand, by comparing the Christian and Islamic doctrine on revelation, as we have already done, this unqualified centrality of Christ, who God is revealing, God revealed, and the sign of revelation becomes more obvious. On the other hand, by contrasting Jesus Christ with the Qur'ān on the basis of their roles in their respective traditions as the Word of God, we are more aware of the very identity of Christian revelation.

As a study in comparative theology, we have showed that even such a modest comparison can open new ways to deepen the Christian faith in the incarnate Word of God and, at the same time, to go beyond tolerance, to respectfully appreciate Muslims' faith.

\section{Y.B. Prasetyantha}

Graduate of Doctoral Programs in Pontifical Gregorian University, Lecturer at the Faculty of Theology, University of Sanata Dharma Yogyakarta;

Email:prasetyanth@yahoo.com

\section{ENDNOTE}

1 Johannes Deninger, "Revelation", The Encyclopedia of Religion 12 (1987), 356.

2 In this article all citations from the translation of the Qur'an are taken from: Arthur J. Arberry, The Koran Interpreted, Oxford $1982^{2}$. To refer to chapters and verses from the Qur'ān we have used this edition.

31 S 9,15; Ps 119,18.

4 Ex 6,2.

5 Gn 32,30; 41,25; Is 42,12; Jb 11,6.

6 Johannes Deninger, "Revelation", 359.

7 René Latourelle, Theology of Revelation, New York 1987, 59

8 René Latourelle, Theology of Revelation, 368.

9 Keith Ward, Religion and Revelation, 188-189.

10 Seyyed Hossein Nasr, Ideals and Realities of Islam, New Delhi 1979, 41.

11 In Muslim tradition, it is recalled that Adam built the first Ka'ba at Mecca on the model of a heavenly prototype. However, it was no longer standing in Abraham's day as the resumption of Tha'alibi's narrative explains. On this site already hallowed by Adam, the patriarch Abraham on a visit to his son Ishmael in Mecca put down on God's command the foundation of the Sacred House as alluded to in the Qur'ān 2:122. (F. E. Peters, A Reader on Classical Islam, New Jersey 1994, 11-20.)

12 Keith Ward, Religion and Revelation, 186.

13 Jn 16,8

14 René Latourelle, Theology of Revelation, 439.

15 Daniel A. Madigan, The Qur'ân Self-Image, Writing and Authority in Islam's Scripture, New Jersey 2001, 133.

16 Shabbir Akhtar, "An Islamic Model of Revelation", Islam and Christian-Muslim Relations 2 (1, 1991), 101. 
17 Charles J. Adams, "Qur'ān, The Text and Its History", The Encyclopedia of Religion 12 (1987) 174.

18 Wilfred Cantwell Smith, "The True Meaning of Scripture: An Empirical Historian's non-Reductionist Interpretation of the Qur'an”, International Journal of Middle Eastern Study 11 (1980): 490.

19 René Latourelle, Theology of Revelation, 458.

20 Nicene Creed: Denz. 125; ND 7.

21 Constantinopolitan Creed: Denz. 150; ND 12.

22 Karl Rahner, Foundations of Christian Faith, An Introduction to the Idea of Christianity, New York $2000^{2}, 136$.

23 Karl Rahner, The Trinity, New York 1997², 21.

24 Toshihiko Izutsu, God and Man in the Koran, Semantic of the Koranic Weltanschauung, Tokyo 1964, 75.

25 C. Van Arendonk, "Salām", The Encyclopaedia of Islam 8 (1995) 915.

26 Anthony Hearle Johns, "Fall of Man", Encyclopaedia of the Qur'ān 2 (2002) 173.

27 Farid Esack, The Qur'an, A Short Introduction, Oxford 2002, 166.

28 Ella Landau-Tasseron, "Jihād", Encyclopaedia of the Qur'àn 3 (2003) 38.

29 'Il 'cammino della salvezza', che vi conduce, è una condotta della vita nel segno della dedizione a Dio con l'indispensabile ricorso alla personale volontà di lottare per escludere dalla propria esistenza il ruolo delle passioni basse. Questo è in realtà il senso di un Islam massimalistico (djih $\bar{a} d)$. Su questo piano si svolge l'autoredenzione dei credenti. L'autoredenzione, incentrata su una purificazione morale che termina con la rinuncia a se stessi, viene praticata con particolare energia dai Süfĭ. Le loro pratiche e le loro idee producono anche altri punti d'incontro con il Cristianesimo, ma anche con il Buddhismo. La 'mèta della salvezza' dell'Islam è la visione di Dio o quanto meno la sua soddisfazione. Questa mèta viene spostata dai Sūfí ancor più avanti: è la unio mystica (al-fanā' fillāh)." (S. Balić, "Salvezza Islamica", Islam, Cristianesimo, Ebraismo a confronto (1991) 647.

30 Farid Esack, The Qur'an, A Short Introduction, 178.

31 René Latourelle, Theology of Revelation, 396.

32 René Latourelle, "Moral Evil", Dictionary of Fundamental Theology $\left(2000^{2}\right) 730$.

33 Quoted in Stephen J. Duffy, The Dynamics of Grace: Perspectives in Theological Anthropology, Minnesota 1993, 64.

34 Stephen J. Duffy,, The Dynamics of Grace, 384.

35 Edward Schweizer, The Holy Spirit, Philadelphia 1978, 109-110.

36 Council of Trent (1547): Denz. 1576.

37 Hans Zirker, "Revelation in History and Claims to Finality: Assumptions Underlying Fundamentalism in Christianity and Islam", Journal Study of Islam and Christian-Muslim Relations 3 (2,1992) 214.

38 Qur'ān 42:50-51.

39 Farid Esack, The Qur'an, A Short Introduction, 42.

40 See Gisela Webb, "Angel", Encyclopaedia of the Qur'ān 1 (2001) 87-89; Sidney H. Griffith, "Holy Spirit", Encyclopaedia of the Qur'ān 2 (2002) 442444.
41 However, as William Graham observes, it should be noted that "there are several indications that the relationship of the Prophet to the specifically Qur'ânic revelations was early understood in much more complex ways than was generally recognized later on. ... One particular aspect of this complexity is the traditional evidence that Muhammad received Qur'ânic revelation directly from God as well as through the medium of Gabriel. ... This is most evident in the traditions about the famous mi râj, or 'ascent [to Heaven]', which is mentioned in Sûrahs 81:19-25 and 53:1-12, 13-18. This was apparently a visionary experience, and it is linked traditionally with the isrâ', or 'night journey', referred to in Sûrah $17: 1$, and even on occasion with the story of the cleansing of Muhammad's heart by the angels. The idea of this journey, in which the Prophet is said to have met God face to face and even to have received revelation from Him, exists alongside the traditional tendency to view Gabriel as the sole medium of revelation to Muhammad. The question of the nature of the heavenly journey - i.e., whether it was corporeal or visionary - became a major issue in later theological discussion, principally with regard to the 'seeing of God' (ru'yat Allâh) by Muhammad on the mi râj." (William A. Graham, Divine Word and Prophetic Word in Early Islam, The Hague-Paris 1977, 26-28.)

42 Farid Esack, The Qur'an, A Short Introduction, 3133.

43 Qur'ān 97:1-5.

44 Farid Esack, The Qur'an, A Short Introduction, 31.

45 Shabbir Akhtar, "An Islamic Model of Revelation”, 96.

46 Shabbir Akhtar, "An Islamic Model of Revelation", 99.

47 Shabbir Akhtar, "An Islamic Model of Revelation", 103-104.

48 Farid Esack, The Qur'an, A Short Introduction, 43.

49 Shabbir Akhtar, "An Islamic Model of Revelation", 99.

50 René Latourelle, Theology of Revelation, 327.

51 Keith Ward, Religion and Revelation, 193.

52 Council of Chalcedon (451): Denz. 301-302; ND 614-615.

53 René Latourelle, Theology of revelation, 349.

54 René Latourelle, Theology of revelation, 364.

55 Karl Rahner, Foundations of Christian Faith, 174175.

56 René Latourelle, Theology of Revelation, 369.

\section{BIBLIOGRAPHY}

Adams, C. J."Qur'ān, The Text and Its History", The Encyclopedia of Religion 12 (1987): 156-176.

Akhtar, S. "An Islamic Model of Revelation". Islam and Christian-Muslim Relations 2 (1, 1991): 95-106.

Arberry, A. J. The Koran Interpreted. United Kingdom: Oxford, 1982. 
Arendonk, C. V. "Salām", The Encyclopedia of Islam 8 (1995), 915-917.

Balić, S. "Salvezza Islamica", Islam, Cristianesimo, Ebraismo a confronto, (1991) 647.

Deninger, J. "Revelation", The Encyclopedia of Religion 12 (1987) 356-362.

Duffy, S. J. The Dynamics of Grace: Perspectives in Theological Anthropology. Minnesota, 1993

Esack, F. The Qur'an, A Short Introduction. United Kingdom: Oxford, 2002.

Graham, W. A. Divine Word and Prophetic Word in Early Islam. Paris: MoutonThe Hague, 1977.

Griffith, S. H. "Holy Spirit", Encyclopaedia of the Qur'ān 2 (2002): 442-444.

Izutsu, T. God and Man in the Koran, Semantic of the Koranic Weltanschauung. Tokyo, 1964.

Johns, A. H. "Fall of Man", Encyclopaedia of the Qur'ān 2 (2002) 172-173.

Landau-Tasseron, E. “Jihād”, Encyclopaedia of the Qur'ān 3 (2003) 39-42.

Latourelle, R. Theology of Revelation. New York, 1987.

Latourelle, R. "Moral Evil", Dictionary of Fundamental Theology (2000) 725732.
Madigan, D. A. The Qur'ân Self-Image, Writing and Authority in Islam's Scripture. Princeton, 2001.

Nasr, S. H. Ideals and Realities of Islam New Delhi, 1979.

Peters, F. E. A Reader on Classical Islam. Princeton, 1994.

Rahner, K. Foundations of Christian Faith, An Introduction to the Idea of Christianity. New York, 2000.

Rahner, K. The Trinity. New York, 1997.

Schweizer, E. The Holy Spirit. Philadelphia, 1978.

Ward, K. Religion and Revelation, A Theology of Revelation in the World's Religions. United Kingdom Oxford, 1994.

Webb, G. "Angel", Encyclopaedia of the Qur'ān 1 (2001) 86-89.

Wilfred Cantwell Smith. "The True Meaning of Scripture: An Empirical Historian's non-Reductionist Interpretation of the Qur'an", International Journal of Middle Eastern Study 11 (1980): 487-505.

Zirker, H. "Revelation in History and Claims to Finality: Assumptions Underlying Fundamentalism in Christianity and Islam", Journal Study of Islam and Christian-Muslim Relations 3 (2, 1992): 211-235. 